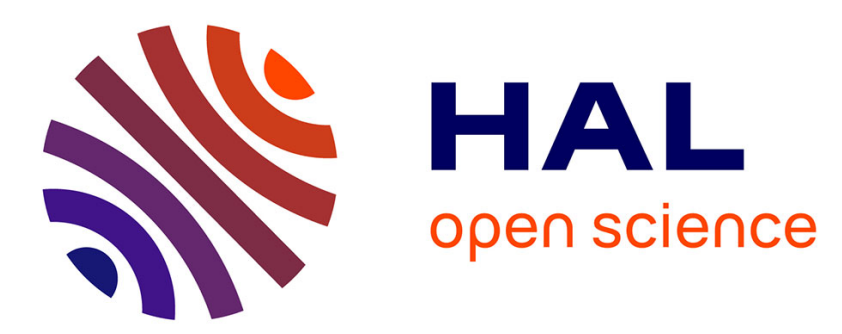

\title{
Inferences from the vertical distribution of Fe isotopic compositions on pedogenetic processes in soils
} Zuzana Fekiacova, Sylvain Pichat, Sophie Cornu, Jérôme Balesdent

\section{To cite this version:}

Zuzana Fekiacova, Sylvain Pichat, Sophie Cornu, Jérôme Balesdent. Inferences from the vertical distribution of Fe isotopic compositions on pedogenetic processes in soils. Geoderma, 2013, 209-210, pp.110-118. 10.1016/j.geoderma.2013.06.007 . hal-00913103

\section{HAL Id: hal-00913103 https://hal.science/hal-00913103}

Submitted on 3 Dec 2013

HAL is a multi-disciplinary open access archive for the deposit and dissemination of scientific research documents, whether they are published or not. The documents may come from teaching and research institutions in France or abroad, or from public or private research centers.
L'archive ouverte pluridisciplinaire HAL, est destinée au dépôt et à la diffusion de documents scientifiques de niveau recherche, publiés ou non, émanant des établissements d'enseignement et de recherche français ou étrangers, des laboratoires publics ou privés. 
1 Inferences from the vertical distribution of Fe isotopic compositions

2

$$
\text { on pedogenetic processes in soils }
$$

3 Z. Fekiacova ${ }^{1}$, S. Pichat ${ }^{2}$, S. Cornu ${ }^{1}$ and J. Balesdent ${ }^{1}$

4

5

$6{ }^{1}$ INRA - UR1119 Géochimie des sols et des eaux, Europôle méditerranéen de l'Arbois, F-

713545 Aix-en-Provence Cedex 04,

$8{ }^{2}$ Laboratoire de Géologie de Lyon, Ecole Normale Supérieure de Lyon, Université Claude

9 Bernard, CNRS, UMR 5276, 69007 Lyon, France

10

11 Corresponding author: Zuzana.Fekiacova@aix.inra.fr

12 


\section{ABSTRACT}

The isotopic compositions of major elements in soils can help understand the

3 mechanisms and processes that control the evolution of soils and the nature and dynamics of 4 the soil constituents. In this study, we investigated the variations of the Fe concentrations and 5 isotopic compositions combined with classical soil parameters, such as granulometry, $\mathrm{pH}$, 6 and $\mathrm{C}$ and $\mathrm{N}$ concentrations. We selected three soils submitted to different hydrodynamic 7 functioning along a toposequence: a well-drained Cambisol and two hydromorphic soils, an 8 Albeluvisol and a Gleysol. In the Cambisol, the isotopic variations were small indicating little 9 redistribution of Fe which we attributed to centimetric-scale exchanges from the Si-bound to 10 the weakly-bound iron pools and insignificant subsurface Fe export. In contrast, the 11 hydromorphic soils showed an overall variation of $0.37 \%$ for $\delta^{56} \mathrm{Fe}\left(\delta^{56} \mathrm{Fe}(\%)=\right.$ $\left.12\left[\left({ }^{56} \mathrm{Fe} /{ }^{54} \mathrm{Fe}\right)_{\text {sample }} /\left({ }^{56} \mathrm{Fe} /{ }^{54} \mathrm{Fe}\right)_{\mathrm{IRMM}-014}-1\right] \times 1000\right)$ and an inverse correlation between the $\mathrm{Fe}$ 13 isotopic compositions and the oxide-bound $\mathrm{Fe}$ concentrations. We suggest that, in the 14 uppermost horizon, the mobilisation of oxide-bound Fe was due to the reducing conditions 15 and predominantly involved the light Fe isotopes. Similarly, within the Bt horizon of the 16 Albeluvisol, the fluctuations of the water table level induced changes in the redox conditions 17 and thus Fe dissolution and transport of isotopically light Fe. The Fe isotopic composition 18 profile in the $\mathrm{B} / \mathrm{C}$ horizon of the Gleysol is dominated by the signature of the parental 19 material. Overall, the variations of the underground water table combined with topography20 driven water flow were suggested to be the main mechanisms of Fe translocation in these hydromorphic soils. Finally, the comparison between Fe isotopes profiles in worldwide soils allow us to show that $\mathrm{Fe}$ isotopic variations can help discriminate between various mechanisms and scales of Fe transfer in soils and, accordingly, provide information on the

24 evolution of soils, when used in combination with pedological, geochemical, geographical, and environmental characterisations. 
1 Key Words: iron isotopes, soil toposequence, hydromorphy, world soils

\section{Highlights}

3 - This study investigates the Fe behaviour in three soils along a toposequence.

4 - Fe transport mechanisms were studied using Fe isotopes and classical soil parameters.

5 - In the Cambisol, Fe transfer is limited; in-situ Fe transformations were dominant.

6 - In the hydromorphic soils, the oxide-bound Fe controls the Fe transformations.

7 - Iron isotope ratio variations in soils help distinguish soil evolution processes. 


\section{1. Introduction}

Understanding mechanisms and processes that control soil evolution, the nature and dynamics of major soil constituents and their behaviour in response to natural and anthropogenic changes is among the key scientific challenges in soil research. Iron is one of the major elements in soils. It is released during the alteration of rocks and soils, and participates in mineral neoformation, thereby playing a crucial role in soil differentiation.

Iron concentration in soil varies because of different processes: physico-chemical redistributions without transport and short-distance or long-range transport of Fe. In addition, the fate of Fe influences the chemical cycles of other important elements in soils, such as nutrients (e.g. P, Zn) and pollutants (e.g. As, Cd, Zn) (e.g. Anderson and Christensen, 1988; Jacobs et al., 1970; Ramos et al., 1993). Finally, Fe is an essential micronutrients for plants (Marschner, 1995) and human nutrition (WHO, 2002).

Stable isotopes analyses have proven to be valuable tools to understand biogeochemical processes in soils (e.g. Fry, 2006). Until the end of the 90's, these studies were limited to $\mathrm{C}, \mathrm{N}, \mathrm{O}, \mathrm{H}$, and $\mathrm{S}$. However, significant analytical developments over the past years, notably due to the advent of Multi-Collector Inductively-Coupled Plasma MassSpectrometers (MC-ICP-MS), now allow high-precision analyses required to measure the small isotopic variations of the so-called "non-traditional" stable isotopes that include Fe (e.g. Albarède and Beard, 2004; Dauphas and Rouxel, 2006). Iron has four stable isotopes, ${ }^{54} \mathrm{Fe}$, ${ }^{56} \mathrm{Fe},{ }^{57} \mathrm{Fe}$ and ${ }^{58} \mathrm{Fe}$. The $\delta$-notation is commonly used to describe the isotopic fractionation relative to the isotopic reference material IRMM-014: $\delta^{\mathrm{X}} \mathrm{Fe} \quad(\%$ o) $=$ $\left[\left({ }^{\mathrm{X}} \mathrm{Fe} /{ }^{54} \mathrm{Fe}\right)_{\text {sample }} /\left({ }^{\mathrm{X}} \mathrm{Fe} /{ }^{54} \mathrm{Fe}\right)_{\mathrm{IRMM}-014}-1\right] \times 1000$, where $\mathrm{X}=56,57$ or 58.

In natural environment, $\delta^{56} \mathrm{Fe}$ ranges between $-3.5 \%$ and $+1.5 \%$ (Beard et al., 2003a; Beard and Johnson, 2004; Dauphas and Rouxel, 2006). Igneous rocks represent an 
1 isotopically homogeneous terrestrial baseline $\left(\delta^{56} \mathrm{Fe}=0.0 \pm 0.05 \%\right.$ ) (Beard et al., 2003a),

2 whereas isotopic heterogeneities were initially measured mostly in rivers and lakes, rocks and

3 minerals formed at low temperature, hydrogenous ferromanganese precipitates, pyrites and

4 hydrothermal systems (e.g. Dauphas and Rouxel, 2006; Fantle and DePaolo, 2004).

5 Continental weathering involves processes of mechanical and chemical breakdown of

6 rocks and minerals and subsequent soil development. The parent material, i.e., igneous rocks

7 and clastic sediments, show limited isotopic variations: $\delta^{56} \mathrm{Fe}=0.0 \pm 0.3 \%$ (Beard and

8 Johnson, 2004; Fantle and DePaolo, 2004; Johnson et al., 2003). In contrast, soils display a

9 range of variations of the $\delta^{56} \mathrm{Fe}$ from -0.62 to $+0.72 \%$ (Emmanuel et al., 2005; Fantle and

10 DePaolo, 2004; Poitrasson et al., 2008; Thompson et al., 2007; Wiederhold et al., 2007a,

$112007 \mathrm{~b}$ ) indicating that pedogenic processes, leading to soil formation and evolution, generate

$12 \mathrm{Fe}$ isotopes fractionations with respect to the parent material. Experimental studies have shown that mineral dissolution results in the preferential liberation of light Fe isotopes into the solution while the residual material becomes accordingly heavier than the parent material (e.g. Beard et al., 1999; Brantley et al., 2004; Wiederhold et al., 2006). In contrast, sorption of $\mathrm{Fe}(\mathrm{II})$ onto goethite and mineral ferrihydrite neoformation arising from the abiotic oxidation of aqueous Fe(II) into Fe(III) appears to favour the heavy isotopes (Bullen et al., 2001; Icopini et al., 2004). These experimental results have been confirmed by soil studies that show that, in general, the mobile fraction in soils has lighter Fe isotopic composition (Brantley et al., 2004; Fantle and DePaolo, 2004; Thompson et al., 2007; Wiederhold et al., 2007a, 2007b). Therefore, the variations of the Fe isotopic signatures in soils can help to investigate the behaviour of $\mathrm{Fe}$ in the near-surface environment during pedogenesis and to discriminate between potential processes at the origin of soil evolution.

In this study, we investigated both vertical and lateral variations of the $\mathrm{Fe}$ 
1 parameters such as granulometry, $\mathrm{pH}$, and $\mathrm{C}$ and $\mathrm{N}$ concentrations. We used three soil

2 profiles submitted to different hydrodynamic functioning along a toposequence: a well-

3 drained oxic profile and two profiles that are waterlogged during a part of the year. The

4 objectives were to (1) study the expression of the isotopic fractionation of iron in these soils,

5 (2) characterize the mechanisms of Fe transport, (3) compare the results with those obtained

6 in previous studies of the Fe isotopes fractionation in soils and (4) evaluate the potential of Fe

7 isotopes to record information about mechanisms of soil transformations.

\section{2. Material and methods}

\section{2.1. Study area, sampling and soil description}

The sampling area is located in the Kervidy-Naizin catchment that extends over an area of $4.9 \mathrm{~km}^{2}$ in the centre of Brittany, western France and belongs to the Environment Research Observatory (ERO) AgrHyS (response time in Agro-Hydro Systems). The region is characterised by temperate oceanic climate according to the Köppen climate classification, with a mean annual precipitation of $909 \mathrm{~mm}$ and a mean monthly temperature ranging from $5.4^{\circ} \mathrm{C}$ (January) to $17.4^{\circ} \mathrm{C}$ (August). The land-use is dominated by corn and wheat farming, temporary pastures for dairy production and indoor pig-stock breeding.

The soils in this catchment developed from the weathering of the sedimentary Brioverian schist unit (older than $530 \mathrm{Ma}$ ) and eolian Quaternary deposits that overlay locally the bedrock (Olivié-Lauquet et al., 2001; Thomas and Le Berre, 2009; Van Vliet-Lanoe et al., 1998; Walter and Curmi, 1998). The soils are organised in a toposequence consisting of three soil types: (1) a well-drained, cropped Cambisol (IUSS Working Group WRB, 2006) on the upper part of the slope, characterised by oxic conditions, (2) an Albeluvisol (IUSS Working Group WRB, 2006) at midslope, which represents a transition zone between the well-drained cropland and the poorly drained lowermost part of the landscape and (3) a Gleysol (IUSS 
1 Working Group WRB, 2006) developed next to a small creek that flows at the bottom of the

2 slope. The Albeluvisol and Gleysol are planted with poplar trees. Both soils are roughly

3 ploughed every two years to avoid weed growth between the trees (Durand et al., 1998). They

4 both undergo seasonal fluctuations of water saturation, with winter-spring corresponding to a

5 period of reducing chemical conditions while summer, or late summer in the case of the

6 Gleysol, is dominated by oxidative chemical conditions (Davranche et al., 2011; Trolard et

7 al., 2002). The water table in these two soils is located close to the topographic surface

8 (Davranche et al., 2011; Olivié-Lauquet et al., 2001; Pauwels et al., 1996). During rainy

9 periods a temporary water table could develop in the Ap-horizon and lateral drainage could

10 occur.

11 The sampled profiles are located close to the sites C, I and F described by Trolard et 12 al. (2002) for the Cambisol, the Albeluvisol and the Gleysol, respectively. We sampled the soils using an auger with one sample collected every $10 \mathrm{~cm}$ respecting the horizons 14 boundaries.

In the Cambisol, we sampled the Ap- and B-horizons (Supplementary Table 1). The Ap-ploughing horizon (0 to $20 \mathrm{~cm}$ depth) has a silty texture and a dark brown colour (10YR3/1 according to the Munsell chart). The B-horizon (20 to $60 \mathrm{~cm}$ depth) has a silty texture and a yellowish-brown colour (10YR5/6). The ratio of 2-20 $\mu \mathrm{m}$ to $20-50 \mu \mathrm{m}$ fractions is close to one indicating a parent material of eolian origin for the sampled horizons (Walter and Curmi, 1998), likely similar to the loess of northern and/or western Brittany (Haase et al., 2007; Le Calvez, 1979). In the Albeluvisol, we sampled the Ap- and Bt-horizons (Supplementary Table 1). The Ap-horizon (0 to $20 \mathrm{~cm}$ depth) has a silty texture and a dark-brown to greyish colour (10YR3/2 to $10 \mathrm{YR} 4 / 2$ ). The Bt-horizon (20 to $60 \mathrm{~cm}$ depth) is silty with clay concentration increasing with depth. The ratio of $2-20 \mu \mathrm{m}$ to $20-50 \mu \mathrm{m}$ fractions in all the horizons is close 
1 to 2 indicating that the soil profile is developed from the sedimentary Brioverian schist parent 2 material (Walter and Curmi, 1998).

In the Gleysol, we sampled the Ap- and B/C-horizons (Supplementary Table 1). The Ap-horizon ( 0 to $\sim 25 \mathrm{~cm}$ depth) is dark grey (10YR2.5/1) with a silty-sandy-clayey texture. The illuvial $\mathrm{B} / \mathrm{C}$-horizon ( $\sim 30$ to $80 \mathrm{~cm}$ depth) is brown to brown-dark yellow (7.5 to 10YR4/6) with silty to slightly clayey texture. The ratio of $2-20 \mu \mathrm{m}$ to $20-50 \mu \mathrm{m}$ fractions in all the horizons is close to 2 suggesting that the soil mainly developed from the sedimentary Brioverian schist parent material (Walter and Curmi, 1998).

The Albeluvisol and Gleysol contain redoximorphic features such as mottling and rust accumulations in root spaces. These features are of millimetric to centimetric size, of brown, yellowish to red or pale grey to greenish colour. They are sparse in the upper Ap horizon but frequently present in the deeper Bt and B/C horizons of the Albeluvisol and Gleysol.

\subsection{Methods and analyses}

Collected samples were dried at $40{ }^{\circ} \mathrm{C}$ and sieved to $<2 \mathrm{~mm}$. Aliquots were taken for elemental and isotopic analyses.

\subsubsection{Fe concentrations: bulk analyses and selective extractions}

Total iron concentration of the bulk soils was determined on $0.25 \mathrm{~g}$ aliquots. Each aliquot was dissolved in a $\mathrm{HF}-\mathrm{HClO}_{4}$ mixture after calcination of the organic matter $\left(450{ }^{\circ} \mathrm{C}\right)$.

We also used two methods of selective extractions using reducing agents of increasing strength to obtain information about the major pools of iron in the soils studied: (1) the Tamm's extraction in the dark and (2) the citrate-bicarbonate-dithionite (CBD)-extraction.

The Tamm's reagent is a mixture of oxalic acid and ammonium oxalate (Tamm, 1922). The extraction was performed by shaking the sample-solution mixture over 4 hours, at

$2420{ }^{\circ} \mathrm{C}$ and in the absence of light with a solid/liquid ratio of $1.25 \mathrm{~g} / 50 \mathrm{ml}$. This method allows 
1 the extraction of weakly bound, poorly crystalline and organic-bound iron (Duchaufour and

2 Souchier, 1966). For the extraction by CBD, the soil sample was exposed to the reactant

3 mixture at $80^{\circ} \mathrm{C}$ with a solid/liquid ratio of $0.5 \mathrm{~g} / 25 \mathrm{~mL}$ during $30 \mathrm{~min}$. This method extracts

4 the iron bound to oxides and hydroxides (hematite, goethite, lepidocrite) (Mehra and Jackson, 5 1960).

6

7

Bulk soil iron concentrations and iron concentration in the solutions from the partial extractions were analysed using an Inductively Coupled Plasma-Atomic Emission Spectrometer (LAS Arras).

Each extraction was done from an aliquot of the bulk soil. While the Tamm reagent extracts the weakly-bound $\mathrm{Fe}$, the CBD extracts both the weakly bound and the oxide boundFe. We calculated the oxide-bound Fe concentration by subtracting the weakly-bound Fe measured by Tamm reagent extraction from the CBD extraction and the silicate-bound Fe concentration by subtracting the weakly-bound and the oxide-bound iron from the total iron concentration.

\subsubsection{Fe isotope ratios measurements}

Samples for the measurements of Fe isotope ratio were prepared and analysed at the Ecole normale supérieure de Lyon (ENS Lyon), France. An aliquot of each sample was ground using an agate mortar. Approximately $300 \mathrm{mg}$ of sample powder was first treated with $30 \% \mathrm{H}_{2} \mathrm{O}_{2}$ in order to eliminate the organic matter and then dissolved using a mixture of concentrated $\mathrm{HF}-\mathrm{HNO}_{3}-\mathrm{HCl}$ acids, at $\sim 130^{\circ} \mathrm{C}$. Iron was separated and purified by anion exchange chromatography (AG MP1, 100-200 mesh, chloride form). Samples were loaded on the resin in $7 \mathrm{~N} \mathrm{HCl}-0.001 \% \mathrm{H}_{2} \mathrm{O}_{2}$ and $\mathrm{Fe}$ was eluted with $2 \mathrm{~N} \mathrm{HCl}-0.001 \% \mathrm{H}_{2} \mathrm{O}_{2}$ (Maréchal et al., 1999). As anion-resins could fractionate Fe isotopes, complete recovery is necessary. The yield was found to be better than $99 \%$. For the iron isotopes ratios measurements, we used a high-resolution MC-ICP-MS (Nu Plasma 1700, Nu Instruments) at ENS Lyon, operated at a 
1 mass-resolution $(\mathrm{m} / \Delta \mathrm{m})$ of $3000 \pm 100$, in dry plasma mode using the $\mathrm{Nu}$ DSN desolvation

2 system. Samples were introduced by free aspiration in $0.05 \mathrm{~N}$ sub-boiled distilled $\mathrm{HNO}_{3}$ using

3 a glass microconcentric nebulizer (uptake rate: $100 \mu 1 / \mathrm{min}$ ). We used a standard-bracketing

4 approach with IRMM-014 as standard reference material to correct for instrumental mass bias

5 using the exponential law (Albarède and Beard, 2004). Sample measurement solutions were

6 diluted to match the concentration of the IRMM-014 standard within 15\%, i.e. 150 to $300 \mathrm{ppb}$

7 depending on the measurement session. The precision of the isotopic compositions (external

8 reproducibility, $2 \sigma$ ) calculated on the basis of repeated measurement of the IRMM-014

9 standard were 0.11 and $0.17 \%(\mathrm{~N}=324)$ for $\delta^{56} \mathrm{Fe}$ and $\delta^{57} \mathrm{Fe}$, respectively. In a $\delta^{57} \mathrm{Fe}$ vs.

$10 \delta^{56} \mathrm{Fe}$ diagram, all soil samples measurements plot along a line with a slope of 1.46

11 (Supplementary Fig. 1). This value is equal, within error margins, to the theoretical value of $12 \ln (\mathrm{M} 57 / \mathrm{M} 54) / \ln (\mathrm{M} 56 / \mathrm{M} 54)=1.487$, indicating mass-dependent fractionation and no 13 influence of isobaric interferences.

14 3. Results

The results for the three soil profiles are presented in figures 1 and 2 and in supplementary table 1 . Classical soil parameters, such as granulometry, $\mathrm{pH}$, and $\mathrm{C}$ and $\mathrm{N}$ concentrations, as well as Fe concentrations and isotopic compositions are indicated. The last two sets of results are presented in details in the following sections.

\subsection{Fe concentration}

Total iron concentration was found to be uniform along the Ap-B horizons of the

21 Cambisol with only a slight increase at the bottom of the B horizon (Fig. 1). In the

22 Albeluvisol and Gleysol, a sharp decrease (- 330 to 350\%) of the total iron concentration in the surface horizons was observed with respect to the deep horizons (Fig. 1b). In the Bt 
1 horizon of the Albeluvisol, the iron concentration is maximum around $25 \mathrm{~cm}$ depth and

2 decreases slightly below. In the B/C horizon of the Gleysol, the iron concentration increases

3 slightly with depth. In the surface horizons, the Cambisol located at the hilltop had the

4 highest $\mathrm{Fe}$ concentration compared to those of the Albeluvisol and Gleysol. The Fe 5 concentrations measured for the three soils were close to those obtained by X-ray 6 fluorescence by Trolard et al. (2002) for nearby locations of the same soil.

Selective extractions showed that the contributions of the different Fe pools varied between the horizons and the soil types (Fig. 1c-e and supplementary Table 1). The oxidebound Fe, corresponded to 39 to $81 \%$ of the total iron (Supplementary Fig. 2) and its vertical evolution in each soil mimicked that of the total Fe. Fe (Supplementary Fig. 2). It was higher in the Cambisol than in the two other profiles. In the three soils, it increased progressively up to the surface horizon.

The silicate-bound Fe represented 18 to $45 \%$ of the total iron (Supplementary Fig. 2) and decreased gradually from depth to surface in the Cambisol. In the Albeluvisol, it increased progressively from a depth of $60 \mathrm{~cm}$ to reach a maximum around a depth of 20-30 $\mathrm{cm}$, then showed a sharp decrease at the transition between the $\mathrm{Bt}$ and the Ap horizons around $20 \mathrm{~cm}$. For the Gleysol, its maximum value was recorded in the deepest sample and decreased progressively to the top of the $\mathrm{B} / \mathrm{C}$ horizon. A decrease was observed at the $\mathrm{B} / \mathrm{C}-$ Ap transition. The Ap horizons have similar silicate-bound Fe concentrations in the three 21 profiles.

\subsection{Fe isotopic compositions}

The iron isotopic composition in the studied soils varied from $\delta^{56} \mathrm{Fe}=-0.15$ to $0.26 \%$ o

24 (Fig. 2 and supplementary Table 1). The three studied soils show differences in the iron 25 isotopic compositions and variations with depth. The Cambisol profile showed variations of 
$1 \quad \delta^{56} \mathrm{Fe}$ from 0.00 to only $0.15 \%$ indicating virtually no vertical fractionation along this

2 profile. In contrast, the amplitude of the Fe isotopic variations was much larger than the

3 external reproducibility within the two other profiles. In the Albeluvisol, $\delta^{56} \mathrm{Fe}$ ranged from

$4 \quad 0.00$ to $0.26 \%$ with a decrease of the $\delta^{56} \mathrm{Fe}$ values from the surface down to ca. $40 \mathrm{~cm}$. In the

5 Gleysol, $\delta^{56} \mathrm{Fe}$ varies from -0.15 to $0.22 \%$ with values decreasing with depth. Notably a

6 marked decrease $(-0.19 \%$ ) was found between the surface Ap horizon and the deeper B/C

7 horizon, corresponding to the observed increase in total Fe concentration (Fig. 1b) and

8 variations in the relative proportions of the various Fe pools (Supplementary Fig. 2). In both

9 the Albeluvisol and the Gleysol, the surface horizons were enriched in heavy Fe isotopes

10 while the deep horizons were enriched in light isotopes (Fig. 2). The non-hydromorphic

11 Cambisol exhibited the lowest $\delta^{56} \mathrm{Fe}$ value and the highest Fe concentration in the surface

12 horizon whereas it was the opposite for the hydromorphic Albeluvisol and Gleysol.

\section{4. Discussion}

Heterogeneities observed in soils can result from different pedogenetic processes and factors, such as the parent material and topography (Jenny, 1941) that contribute to the soil formation. The soils studied in this work can be differentiated by two main factors: the parent material and the water regime. The Cambisol developed on material of eolian origin under oxic conditions in a well-drained environment. In contrast, the other two soils formed on sedimentary Brioverian schists and remain waterlogged during a great part of the year and are thus subject to reduction processes. The evolution of the Fe behaviour with depth will thus be

21 discussed separately, on the one hand in the Cambisol and on the other hand in the two waterlogged soils in an attempt to identify the mechanisms that control the Fe transfers.

\subsection{Evolution of the Fe in the Cambisol}


In the Cambisol, the amount of oxide-bound $\mathrm{Fe}$ was found to remain constant,

2 whereas the amount of weakly-bound Fe increased and that of Si-bound Fe decreased from

3 the base to the top of the soil profile (Fig. 1c-e). A question arises about whether an exchange

4 could occur between these last two Fe pools and whether Fe remobilization could take place

5 in this soil profile. The Cambisol profile is characterised by an overall homogeneous bulk Fe

6 isotopic signature (Fig. 2): $\delta^{56} \mathrm{Fe}=0.00$ to $0.15 \%$. Two scenarios could explain this rather

7 uniform isotopic composition: (1) Fe redistribution processes took place but did not

8 fractionate the $\mathrm{Fe}$ isotopes or (2) soil evolution processes happened at the centimetric to

9 decimetric scale, i.e. no major vertical Fe translocation occurred in this soil and Fe export out

10 of this soil was extremely limited. In the deepest sample having the highest Si-bound Fe

11 value, the total $\mathrm{Fe}$ concentration was $31.1 \mathrm{~g} \mathrm{~kg}^{-1}$ and the $\delta^{56} \mathrm{Fe}$ was $0.0 \%$. This concentration

12 value is within the range of those of Brittany loess $\left(22.0 \pm 17.2 \mathrm{~g} \mathrm{~kg}^{-1}(2 \sigma)\right.$, Gallet et al.

13 (1998)). In addition, both the concentration and isotopic composition values are, within

14 experimental error, close to those of worldwide loess: $\left[\mathrm{Fe}_{\text {total }}\right]=22.7 \pm 8.8 \mathrm{~g} \mathrm{~kg}^{-1}$ (Taylor et

15 al., 1983) and $\delta^{56} \mathrm{Fe}=0.05 \pm 0.04 \%$ (Beard et al., 2003b). Both observations are in

16 agreement with the fact that the loess is the parent material of the Cambisol (see section 2.1).

17 Mineral weathering by hydrolysis in the surface soil could have liberated Si-bound Fe as

18 indicated by the lower values relative to the rest of the profile (Fig. 1e). The comparison

19 between the average value of the Ap horizon and the deepest sample of the B horizon shows

20 that there is a $4.7 \mathrm{~g} \mathrm{~kg}^{-1}$ decrease of the total Fe concentration in the surface horizon (Fig. 1b).

21 In addition, in the homogenous Ap-horizon, $4.4 \mathrm{~g}_{\mathrm{Fe} \mathrm{kg}} \mathrm{kg}^{-1}$ is lost from the silicate compartment

22 (Fig. 1e) while $2.2 \mathrm{~g}_{\mathrm{Fe} \mathrm{kg}} \mathrm{kg}^{-1}$ is gained in the weakly-bound $\mathrm{Fe}$ pool (Fig. 1d). These

23 observations show that part of the iron is removed from the profile. The loss in the Ap

24 horizon corresponds, however, to a very small decrease of the total Fe concentration (ca.

$2515 \%$ ) between the deepest sample and the two surface samples of the ploughing horizon. 
1 There is also an in-situ transfer from the Si-bound to the weakly-bound iron pool representing

2 about half of the mobilised Fe. To summarize, the redistribution of Fe in the Cambisol was

3 found to be very limited and the net loss of Fe too small to generate significant Fe isotopes

4 fractionation over the Cambisol profile.

\subsection{Fe transport in the hydromorphic soils (Albeluvisol and Gleysol)}

The oxide-bound $\mathrm{Fe}$ is the dominant pool of $\mathrm{Fe}$ in the hydromorphic soils investigated (Fig. 1c and supplementary Fig. 2a). There is a sharp decrease in the oxide-bound Fe concentration in the surface horizons in both soils concomitant with a decrease in total Fe concentration (Fig. 1b, c) suggesting that there is a net export of Fe from these surface horizons. This export can be explained by the presence of a water table that develops in the surface horizons during winter-spring and creates reducing conditions favourable to $\mathrm{Fe}$ remobilization. The similarity of both the total Fe concentrations (Fig. 1b) and the isotopic compositions (Fig. 2) in the surface horizons of these soils suggests that the Fe transport in these soils is due to the same process. Dissolution of Fe in the surface horizons would create (1) a decrease in the Fe concentration (Fig. 1b) and (2) a residual Fe pool enriched in heavy isotopes (Fig. 2) because light Fe isotopes are preferentially remobilized by dissolution. The isotopically light product of the dissolution reaction could be transported laterally out of the soil profiles along the topography or vertically to greater soil depth.

The iron isotopic composition of the bulk soil is mostly controlled by this process as shown by the strong negative correlation $\left(\mathrm{R}^{2}=0.70, \mathrm{p}<0.01\right.$, data normally distributed $)$ between the $\delta^{56} \mathrm{Fe}$ of the bulk soil samples and the oxide-bound Fe concentration (Fig. 3). Accordingly, the dissolution of Fe-bearing minerals and transport of the free Fe (II) would be the processes that dominate the Fe movements in these hydromorphic soils. 
By contrast, as aforementioned, there is no relationship between the oxide-bound Fe

2 concentration and the $\delta^{56} \mathrm{Fe}$ value of the bulk soil samples in the Cambisol (Fig. 3). This

3 confirms that the mechanism governing the evolution of $\mathrm{Fe}$ in the Cambisol is different from

4 that involved in the Albeluvisol and Gleysol.

5 The Albeluvisol and Gleysol profiles below the Ap horizon are more difficult to

6 interpret. Both soils developed from a sedimentary Brioverian schist parent material (see

7 section 2.1) which is a highly heterogeneous material as shown, in particular, by the complex

8 evolution of the Si-bound iron profiles. Thus, no mass balance calculations could be

9 performed.

10 In the $\mathrm{B} / \mathrm{C}$ horizon of the Gleysol, the observed overall variation of the Fe isotopic composition with depth is almost an inverse image of the variation of the Si-bound Fe with

12 depth (Figs. 1e and 2). Indeed, there is a strong negative correlation between the $\delta^{56} \mathrm{Fe}$ and the Si-bound concentrations (Supplementary Fig. 3a). This feature could be interpreted as reflecting the imprint of the parental material on the isotopic composition of the Gleysol. Thus, the isotopic composition of the parental material appears to be the main factor that governs the $\mathrm{Fe}$ isotopic signature of the $\mathrm{B} / \mathrm{C}$ horizon of the Gleysol. On the contrary, there is no such relationship in the Bt horizon of the Albeluvisol (Supplementary Fig. 3b). Thus, the parental material has little influence, if any, on the Fe isotopic composition of the Albeluvisol Bt profile.

In the Bt horizon of Albeluvisol, the two deepest samples are both enriched in Fe heavy isotopes and depleted in oxide-bound Fe relative to the corresponding Gleysol samples (Figs. 1c and 2). In addition, the Fe concentration profiles (Figs. 1b-e) could reflect a greater dissolution of Fe with increasing depth. Indeed, an underground water table is seasonnaly present in the Bt horizon of the Albeluvisol (see section 2.1; Davranche et al., 2011; Olivié- 
1 dissolution and the remobilisation of oxide-bound $\mathrm{Fe}$ from the flooded horizons of the

2 Albeluvisol. This process favours the removal of light $\mathrm{Fe}$ isotopes and leaves a residual $\mathrm{Fe}$

3 pool enriched in heavy isotopes. This is in agreement with the observed negative correlation

4 between the $\delta^{56} \mathrm{Fe}$ of the bulk soil samples and the oxide-bound Fe concentration (Fig. 3).

5 The mobile, isotopically light Fe(II), could be transported down the topography. Thus, the

6 main process that appears to drive the Fe isotopic composition in the Bt horizon of the

7 Albeluvisol is dissolution due to the variation of the level of the underground water table.

Our results suggest that both, variation of the underground water level and

9 topography-driven lateral water flows are involved in the translocation of $\mathrm{Fe}$. The

10 isotopically-light Fe removed from the Albeluvisol could be redeposited deeper within the

11 Albeluvisol or in the Gleysol located down the slope or be evacuated from the toposequence.

12 Due to the lack of data on the Fe concentration and isotopic composition on the parent

13 material we have however no clear evidence for such redeposition. This study demonstrates

14 that Fe isotopic compositions can evidence Fe transfers where mass balance calculations are

15 not feasible and pinpoint the factors that control the distribution of Fe within a soil profile.

\section{3. Comparison to Fe isotopic compositions in worldwide soils}

We have compiled published Fe isotope composition of bulk horizons from different soil types (Table 1 and Fig. 4). The overall range for the bulk soil is $\delta^{56} \mathrm{Fe}=-0.62$ to $0.72 \%$.

We have divided the soils into two groups on the basis of the range of their isotopic variations and we have tried to pinpoint the common characteristics for the soils in each group in an attempt to distinguish the factors that control the Fe isotopic fractionations.

Group 1 is formed by the soils with small vertical Fe isotopic fractionation, i.e.

$\Delta^{56} \mathrm{Fe}_{\text {profile }} \leq 0.15 \%$, with $\Delta^{56} \mathrm{Fe}_{\text {profile }}$ being the difference between the highest and the lowest

$24 \delta^{56} \mathrm{Fe}$ values in a given profile (Table 1 and Fig. 4). It regroups the Cambisols $\left(\Delta^{56} \mathrm{Fe}_{\text {profile }}=\right.$ 
10.08 to $0.15 \%)$, the Ferralsols $\left(\Delta^{56} \mathrm{Fe}_{\text {profile }}=0.08\right.$ to $0.14 \%$ o $)$ and the Haplic Gleysol $2 \quad\left(\Delta^{56} \mathrm{Fe}_{\text {profile }}=0.11 \%\right.$ )

3 Group 2 consists of soils with significant Fe isotopic fractionation along a vertical 4 profile, such as the Podzols $\left(\Delta^{56} \mathrm{Fe}_{\text {profile }}=0.24\right.$ to $0.77 \%$, the Albeluvisol $\left(\Delta^{56} \mathrm{Fe}_{\text {profile }}=0.26\right.$ $5 \%$ \% , the Gleysol $\left(\Delta^{56} \mathrm{Fe}_{\text {profile }}=0.41 \%\right)$, the Ultisol $\left(\Delta^{56} \mathrm{Fe}_{\text {profile }}=0.74 \%\right)$ and the Andosol $6 \quad\left(\Delta^{56} \mathrm{Fe}_{\text {profile }}=0.30 \%\right.$ o $)$.

Within group 1, the Cambisols and the Ferralsols develop under oxic and well-drained conditions with a dominant vertical water transfer. Yet, the absence of the Fe isotopic

9 fractionation along the profile suggests that either the water circulation has no effect on the oxidation state of Fe as suggested for Ferralsols by Poitrasson et al. (2008), or that mineral dissolution is not associated with long-distance transfer of Fe and that the released Fe precipitates to form secondary minerals without transport as suggested by Wiederhold et al. (2007a). It is worth noticing that the temporal evolution of the soils does not appear to influence the isotopic signature; indeed, the Cambisols were young, poorly developed soils, whereas the Ferralsols result from a long-term evolution, up to several millions of years (Poitrasson et al., 2008).

The Haplic Gleysol and the Stagnic Cambisol show a range of $\delta^{56} \mathrm{Fe}$ variations similar to those of the other profiles of group $1\left(\Delta^{56} \mathrm{Fe}_{\text {profile }}<0.15 \%\right)$, however, they developed under seasonally or permanently water-saturated, anoxic conditions (Wiederhold et al., 2007b). While reductive Fe mobilization under anoxic conditions was inferred to occur in both soils (Wiederhold et al., 2007b), the absence of large isotopic variations was suggested to indicate that the transport of Fe within each profile was spatially limited and, hence, that most of the Fe would be transformed at the centimetric to decimetric scale. Group 2 of soil profiles correspond to $\Delta^{56} \mathrm{Fe}_{\text {profile }}>0.15 \%$ (Table 1 and Fig 4 ). The Podzols developed under well-aerated conditions with vertical water transfer (Emmanuel et 
1 al., 2005; Wiederhold et al., 2007a). Unlike Cambisols from group 1 that evolved in similar

2 settings, the Podzols were characterised by acidic $\mathrm{pH}$. Under these $\mathrm{pH}$ conditions, $\mathrm{Fe}(\mathrm{III})$

3 could be dissolved and the released isotopically light Fe could vertically be translocated by

4 organic matter. At depth, isotopically light Fe could precipitate. These processes would result

5 in significant Fe isotopes fractionation.

6 The other soils of group 2 - the Albeluvisol, the Gleysol and the Ultisol - developed

7 under poorly-drained to water-saturated conditions and were subject to variations of the redox

8 conditions due to changes in water-saturation states. In all cases, the reductive dissolution of

9 Fe would affect preferentially the light isotopes which become mobile. Hence, the residual

10 material would become isotopically heavier, while the levels where Fe accumulation occurred

11 would become enriched in isotopically light Fe.

The Andosol has an intermediate behaviour between the Podzols and the watersaturated soils. It formed along volcanic slope in Hawaii with a mean annual precipitation of $143500 \mathrm{~mm} /$ year. Water-saturated (Thompson et al., 2007) and low oxygen availability (Schuur 15 et al., 2001) conditions would take place during the periods of higher precipitation. Iron 16 isotope fractionation would result from the reductive dissolution of $\mathrm{Fe}$, and $\delta^{56} \mathrm{Fe}$ values would increase with increasing removal of Fe.

To conclude, iron isotopes represent a great tool for studying the mechanisms and scales (centimetric- to toposequence-) of Fe transfer in soils and distinguishing between 20 various mechanisms of soil evolution. For these reasons, they should be used in combination 21 with pedological and geochemical characterisation as well as an appropriate characterisation of the geographical and environmental contexts.

\section{Conclusions}


Iron isotopes profiles in soils have been shown to be a tool of great potential to better understand the fate of $\mathrm{Fe}$ in soils and the evolution of soils. In this study, iron isotopic variations have helped us to distinguish between various mechanisms of Fe transport within a soil profile and along a toposequence.

For the Cambisol, Fe isotopic fractionations were small and Fe transfers were limited.

6 The mechanisms corresponding to these observations were: (1) centimetric to decametricscale exchanges between iron pools and (2) lateral transport of Fe down the slope; the latter representing only a small proportion of the total $\mathrm{Fe}$.

The bulk Fe isotopic composition in the hydromorphic soils (Albeluvisol and Gleysol) was found to be dominated by the behaviour of the oxide-bound Fe. In the surface horizon, the main mechanism of Fe transport in these soils is a strong Fe dissolution and transport of isotopically light $\mathrm{Fe}$ out of these horizons. Even if Fe could be transferred within each profile, it would mainly be transported laterally along the slope. The fluctuations of the underground water level could also induced the translocation of $\mathrm{Fe}$ after dissolution of the oxides during the periods of reducing conditions corresponding to the high level stands. Iron isotopic compositions have allowed us to show that this phenomenon is dominant in the Bt horizon of the Albeluvisol. Finally, Fe isotopic composition of the B/C horizon of the Gleysol is dominated by the signature of the parental material. Iron isotopic compositions have allowed us to (1) distinguish between the in-situ processes (centimetric- to decimetric-scale) and the processes inducing Fe transfer at the 21 profile- and toposequence-scale, and (2) identify the mechanisms or factors that control the 22 Fe distribution in soils. Consequently, determining the Fe isotopic compositions represents a powerful tool for studying the fate of Fe in soil systems when no sufficient data are available for full mass balance calculations. 
2 world shows that $\mathrm{Fe}$ isotope ratio variations along a soil profile are linked to the evolution 3 processes that have affected the soil. Hence, Fe isotopic compositions in soils can help us

4 discriminate between various mechanisms of soil evolution when they are used in 5 combination with pedological, geochemical, geographical, and environmental 6 characterisations. 


\section{Acknowledgements}

2 We thank the team of the environmental research observatory (ORE) AgHrys (Response time

3 for hydro-chemical fluxes to the evolution of Agro-Hydro Systems) for providing access to

4 their sampling site, Fabienne Trolard for her help with the sampling, Philippe Télouk for his

5 help with the Nu1700 MC-ICP-MS measurements at the ENS Lyon, Chantal Douchet,

6 Emmanuelle Albalat, and Florent Arnaud-Godet for the maintenance of the clean lab at the

7 ENS Lyon, and Jan Wiederhold for his comments on an early version of this manuscript. We

8 also thank the editor (O.K. Borggaard) and an anonymous reviewer for their detailed and

9 constructive reviews. We thank the INRA for financial support for this project. SP was

10 supported by the CNRS Institut National des Sciences de l'Univers (Interrvie AO 2010) and

11 the Ecole Normale Supérieure de Lyon. 


\section{$1 \quad$ Figure Captions}

2 Fig. 1. Variations of the soil characteristics with depth in the three studied soil profiles. (a)

3 clay concentration, (b) total Fe concentration, (c) oxide-bound Fe extracted with CBD, (d)

4 weakly-bound Fe extracted with Tamm's reagent, and (e) calculated Si-bound Fe (see the

5 Material and Methods section for details). The vertical dashed line in (b) represents the

6 average $\mathrm{Fe}$ concentration $\left(50.5 \mathrm{~g} \mathrm{~kg}^{-1}\right)$ for the $\mathrm{Bt}$ and $\mathrm{B} / \mathrm{C}$ horizons of the Albeluvisol and

7 Gleysol, (see section 4.2 for details).

8 Fig. 2. Variations of the iron isotopic compositions $\left(\delta^{56} \mathrm{Fe}\right)$ with depth in the three studied 9 soil profiles.

10 Fig. 3. Relationship (black line) between the bulk iron isotopic compositions and the oxide11 bound Fe concentration in the Albeluvisol and the Gleysol. There is no relationship for the 12 Cambisol.

13 Fig. 4. Global patterns of bulk Fe isotope ratio variations in the Naizin soils and other soils

14 worldwide. Two behaviours are distinguished: soil profiles with limited $\delta^{56} \mathrm{Fe}$ variations

15 (goup 1), and soils in which significant $\delta^{56} \mathrm{Fe}$ variations were measured (group 2). The details 16 for each soil are indicated in Table 1. 


\section{$1 \quad$ References}

2 Albarède, F., Beard, B.L., 2004. Analytical methods for non-traditional isotopes, in Johnson, C.M., Beard, B.L., Albarède, F. (Eds.), Geochemistry of Non-Traditional Stable Isotopes. Rev. Mineral. Geochem. 55, pp. 113-152.

Anderson, P.R., Christensen, T.H., 1988. Distribution coefficients of Cd, Co, Ni, and Zn in soils, J. Soil Sci. 39, 15-22.

Beard, B.L., Johnson, C.M., 2004. Fe Isotope Variations in the Modern and Ancient Earth and Other Planetary Bodies, in Johnson, C.M., Beard, B.L., Albarède, F. (Eds.), Geochemistry of Non-Traditional Stable Isotopes. Rev. Mineral. Geochem. 55, pp. $319-357$.

Beard, B.L., Johnson, C.M., Cox, L., Sun, H., Nealson, K.H., Aguilar, C., 1999. Iron isotope biosignatures. Science 285, 1889-1892.

Beard, B.L., Johnson, C.M., Skulan, J.L., Nealson, K.H., Cox, L., Sun, H., 2003a. Application of $\mathrm{Fe}$ isotopes to tracing the geochemical and biological cycling of Fe. Chem. Geol. 195, 87-117.

Beard, B.L., Johnson, C.M., Von Damm, K.L., Poulson, R.L., 2003b. Iron isotope constraints on Fe cycling and mass balance in oxygenated Earth oceans, Geology 31, 629-632.

Brantley, S.L., Liermann, L., Guynn, R.L., Anbar, A.D., Icopini, G.A., Barling, J., 2004. Fe isotopic fractionation during mineral dissolution with and without bacteria. Geochim. Cosmochim. Acta 68, 3189-3204.

Bullen, T.D., White, A.F., Childs, C.W., Vivit, D.V., Schulz, M.S., 2001. Demonstration of significant abiotic iron isotope fractionation in nature. Geology 29, 699-702.

Dauphas, N., Rouxel, O., 2006. Mass spectrometry and natural variations of iron isotopes. Mass Spectrom. Rev. 25, 515-550.

Davranche, M., Grybos, M., Gruau, G., Pédrot, M., Dia, A. and Marsac, R. 2011. Rare earth 
element patterns: A tool for idnentifying metal sources during wetland soil reduction. Chem Geol. 284, 127-137.

Duchaufour, P., Souchier, B., 1966. Note sur une méthode d'extraction combinée de l'aluminium et du fer libres dans les sols. Science du sol 1, 17-29.

Durand, P., Henault, C., Bidois, J., Trolard, F., 1998. La dénitrification en zone humide de fonds de vallée, in: Cheverry, C. (Ed), Agriculture intense et qualité des eaux. INRA Editions, Paris, pp. 223-231.

Emmanuel, S., Erel, Y., Matthews, A., Teutsch, N., 2005. A preliminary mixing model for Fe isotopes in soils. Chem. Geol. 222, 23-34.

Fantle, M.S., DePaolo, D.J., 2004. Iron isotopic fractionation during continental weathering. Earth Planet. Sci. Lett. 228, 547-562.

Fry, B., 2006. Stable isotope ecology, Springer, New York, pp 308.

Gallet, S., Jahn, B., Van Vliet-Lanoe, B., Dia, A. and Rossello, E., 1998. Loess geochemistry and its implications for particle origin and composition of the upper continental crust. Earth and Planetary Science Letters, 156: 157-172.

Haase, D., Fink, J., Haase, G., Ruske, R., Pécsi, M., Richter, H., Altermann, M. and Jäger, K.-D. 2007. Loess in Europe - its spatial distribution based on a European Loess Map, scale 1:2,500,000. Quaternary Science Reviews 26, 1301-1312.

Icopini, G.A., Anbar, A.D., Ruebush, S.S., Tien, M., Brantley, S.L., 2004. Iron isotope fractionation during microbial reduction of iron: the importance of adsorption. Geology 32, 205-208.

IUSS Working Group WRB, 2006. World Reference Base for Soil Resources 2006, World Soil Resources Rep. 103, second ed. FAO, Rome.

Jacobs, L.W., Syers, J.K., Keeney, D.R., 1970. Arsenic Sorption by Soils, Soil Sci. Soc. Am. J. $34,750-754$. 
1 Jenny, H. 1941. Factors of soil formation. Dover Publications, New York, pp. 191.

2 Johnson, C., Beard, B., Beukes, N., Klein, C., O'Leary, J., 2003. Ancient geochemical cycling in the Earth as inferred from $\mathrm{Fe}$ isotope studies of banded iron formations from the Transvaal Craton. Contrib. Mineral. Petrol. 144, 523-547.

Le Calvez, L., 1979. Genèse des formations limoneuses de Bretagne centrale: essai de modélisation. Ph. D. thesis, Université de Rennes I.

Maréchal, C.N., Télouk, P. and Albarède, F., 1999. Precise analysis of copper and zinc isotopic compositions by plasma-source mass spectrometry. Chemical Geology 156, 251-273.

Marschner H., 1995. Mineral nutrition of higher plants. Academic Press, London, pp 889.

Mehra, O.P., Jackson, M.L., 1960. Iron oxide removal from soils and clays by a dithionitecitrate system buffered with sodium bicarbonate. Clays Clay Miner. 7, 317-327.

Olivié-Lauquet, G., Gruau, G., Dia, A., Riou, C., Jaffrezic, A. and Henin, O. 2001. Release of trace elements in wetlands: role of seasonal variability. Water Research 35, 943-952.

Pauwels H., Martelat A., Foucher J.C, Lachassagne P . 1996. Dénitrification dans les eaux souterraines du bassin versant du Coet Dan : Suivi géochimique et hydrogéologique du processus. Rapport BRGM R39055, 66 p., 23 fig., 6 tab.

Poitrasson, F., Viers J., Martin, F., Braun, J.J., 2008. Limited iron isotope variation in recent lateritic soils from Nsimi Camerron: Implications for the global Fe geochemical cycle. Chem. Geol. 253, 54-63.

Ramos, L., Hernandez, L.M., Gonzalez, M.J., 1993. Sequential Fractionation of Copper, Lead, Cadmium and Zinc in Soils from or near Donana National Park, J. Environ. Qual. 23, 50-57.

Schuur, E. A. G. 2001 The Effect of Water on Decomposition Dynamics in Mesic to Wet Hawaiian Montane Forests. Ecosystems 4, 259-273. 
1 Schuur, E.A., Chadwick, O.A., Matson, P.A., 2001. Carbon cycling and soil carbon storage in mesic to wet Hawaiian montane forests. Ecology 82, 3182-3196.

Tamm, O., 1922. Eine Method zur Bestimmung der anorganishen Komponenten des Golkomplex in Boden. Medd. Statens skogforsoksanst 19, 385-404.

Taylor, S.R., McLennan, S.M., McCulloch, M.T., 1983. Geochemistry of loess, continental crustal composition and crustal model ages, Geochim. Cosmochim. Acta 47, 18971905.

Thomas, E. Le Berre, P., 2009. Carte géol. France (1/50 000), feuille Josselin (350). Orléans: BRGM. Notice explicative par Thomas, E., Le Berre, P., avec la collaboration de Foucuad-Lemercier B., Le Bris, A.-L., Carn-Dheilly, A., Naas, P. (2009), 90 pp.

Thompson, A., Ruiz, J., Chadwick, O.A., Titus, M., Chorover, J., 2007. Rayleigh fractionation of iron isotopes during pedogenesis along a climatic sequence of Hawaiian basalts. Chem. Geol. 238, 72-83.

Trolard, F., Jaffrezic, A., Bourrié, G. and Robin, P. 1999. Pollution diffuse en zone d'agriculture intensive. INRA USARQ, Rennes, p. 46.

Trolard, F., Bourrié, G., Jaffrezic, A. 2002 Distribution spatiale et mobilité des ETM en région d'élevage intensif, in Baize, D., Tercé, M. (Eds.), Les éléments traces métalliques dans les sols. Approches fonctionnelles et spatiales. INRA Paris, pp 183199.

Van Vliet-Lanoe, B., Pellerin, J., Chauvel, J.J., 1998. Le bassin du Coët-Dan au coeur du massif armoricain. 1. Le cadre géologique et géomorphologique, in Cheverry, C. (Ed.), Agriculture intense et qualité des eaux. INRA Editions, Paris, pp. 11-16.

Walter, C. and Curmi, P., 1998. Les sols du bassin versant du Coët-Dan: organisation, variabilité spatiale et cartographie, in Cheverry, C. (Ed.), Agriculture intense et qualité des eaux. INRA Editions, Paris, pp. 85-105. 
1 WHO (World Health Organization), 2002. The world health report: reducing risks, promoting healthy life, www.who.int/whr/2002/en/index.html

3 Wiederhold, J.G., Kraemer, M., Teutsch, N., Borer, P.L., Halliday, A.N., Kretzschmar, R.,

4

5

6 2006. Iron isotope fractionation during proton-controlled and reductive dissolution of goethite. Environ. Sci. Technol. 40, 3787-3793.

Wiederhold, J.G., Teutsch, N., Kraemer, M., Halliday, A.N., Kretzschmar, R., 2007a. Iron isotope fractionation in oxic soils by mineral weathering and podzolization. Geochim. Cosmochim. Acta 71, 5821-5833.

Wiederhold, J.G., Teutsch, N., Kraemer, M., Halliday, A.N., Kretzschmar, R., 2007b. Iron isotope fractionation during pedogenesis in redoximorphic soils. Soil Sci. Soc. Am. J. $71,1840-1850$. 




Figure 1 


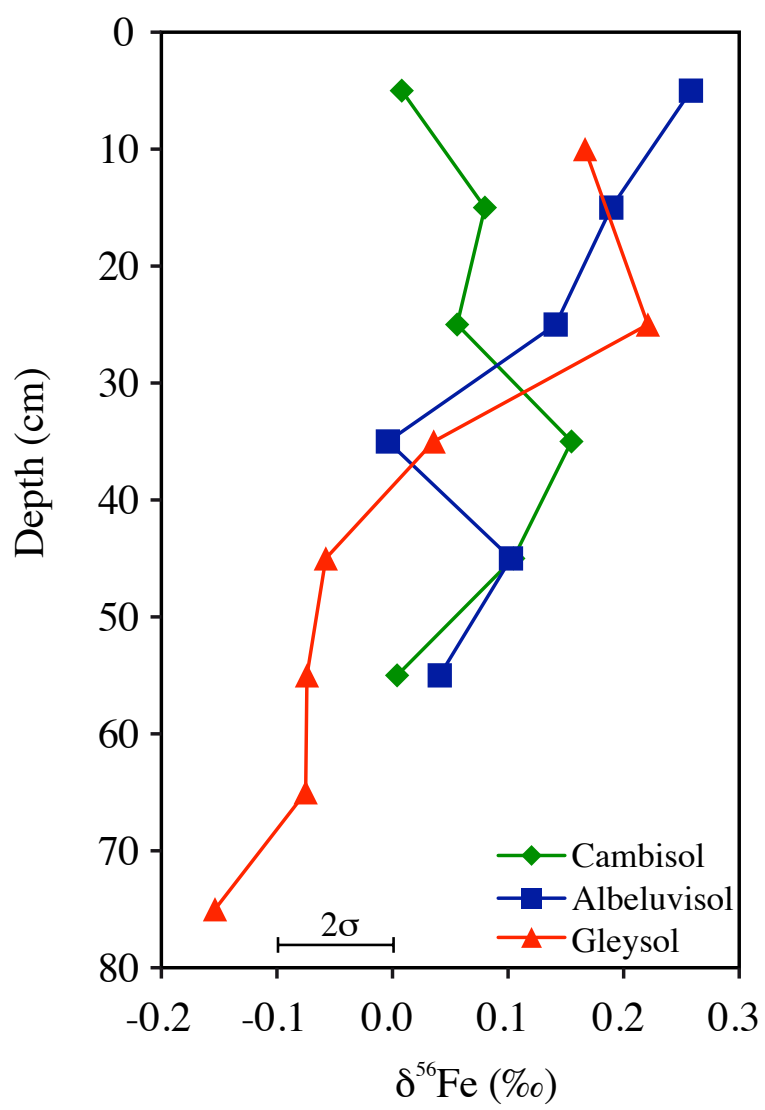

Figure 2 


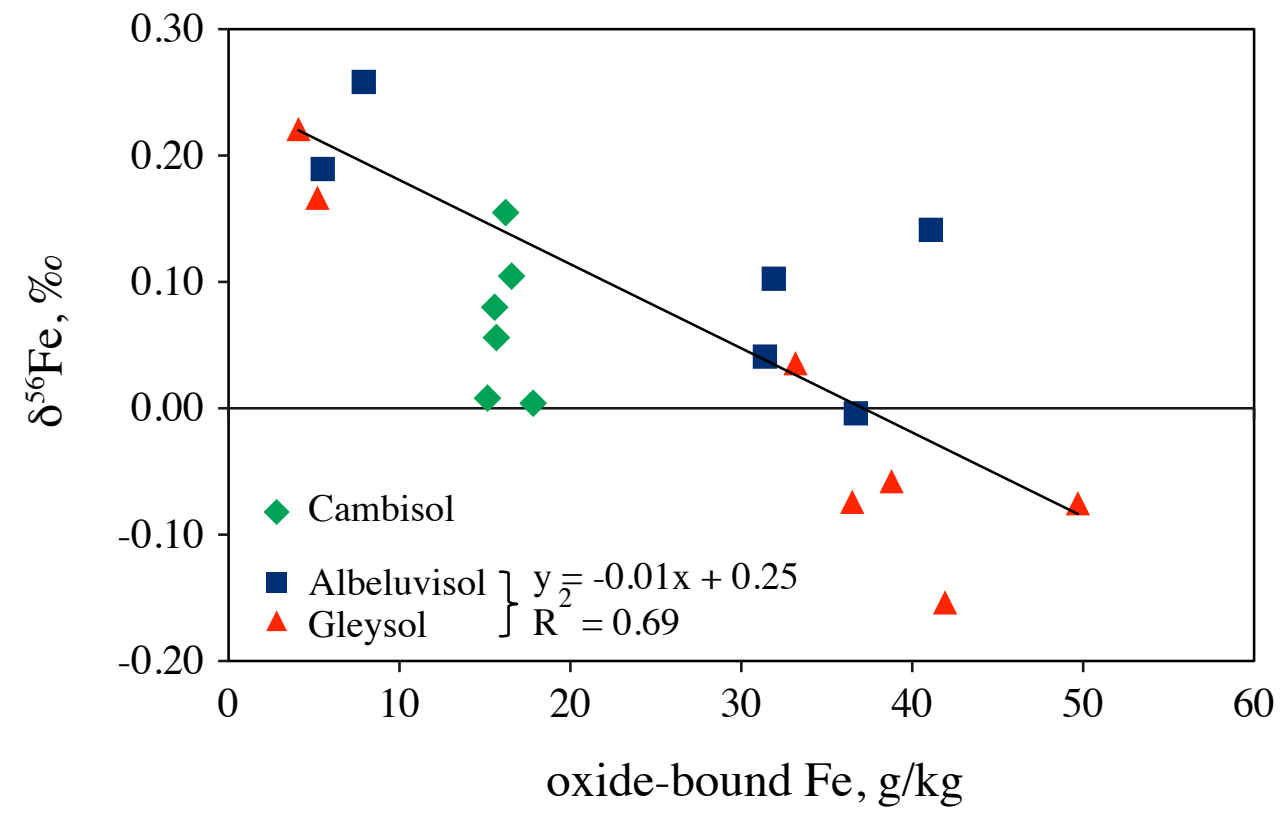

Figure 3 




Figure 4 


\begin{tabular}{|c|c|c|c|c|c|c|c|c|c|c|c|c|c|}
\hline Soil type ${ }^{a}$ & $\begin{array}{c}\text { Soil Type } \\
\text { (as described in } \\
\text { the original paper) }\end{array}$ & Location & Bedrock & Vegetation cover & $\mathrm{pH}$ & $\begin{array}{c}\delta^{56} \mathrm{Fe} \text { range, } \\
\%\end{array}$ & $\begin{array}{c}\Delta^{56} \mathrm{Fe}_{\text {profile }} \\
\% \%\end{array}$ & ${ }^{6} \mathbf{N}=$ & $\begin{array}{l}{[\mathrm{Fe}]} \\
\mathrm{g} / \mathrm{kg}\end{array}$ & Reference & $\begin{array}{l}\text { Differen- } \\
\text { ciation }\end{array}$ & Redox & $\begin{array}{l}\text { Vertical } \\
\text { transfer }\end{array}$ \\
\hline Cambisol (C1) & Cambisol & $\begin{array}{l}\text { Kervidy-Naizin, Brittany, NW France } \\
\left(48^{\circ} 00^{\prime} \mathrm{N}, 2^{\circ} 50^{\prime} \mathrm{W}\right)\end{array}$ & eolian deposits & crop & 6.0 to 6.5 & 0.00 to 0.15 & 0.15 & 6 & 25.8 to 31.1 & this study & - & - & + \\
\hline Cambisol (C2) & $\begin{array}{l}\text { Haplic } \\
\text { Cambisol }\end{array}$ & $\begin{array}{l}\text { Immendingen, Hegau region, SW } \\
\text { Germany, } \\
\left(47^{\circ} 540 \mathrm{~N}, 8^{\circ} 440 \mathrm{E}\right)\end{array}$ & $\begin{array}{l}\text { basaltic tuff (Hewenegg tertiary } \\
\text { volcanic complex) }\end{array}$ & beech trees & 5.5 to 5.9 & 0.11 to 0.21 & 0.10 & 4 & 111.4 to 115.0 & $\begin{array}{l}\text { Wiederhold et al. } \\
\text { (2007a) }\end{array}$ & - & - & + \\
\hline Cambisol (C3) & Haploxerept $^{\mathrm{C}}$ & $\begin{array}{l}\text { Shaar Hagay area, } \\
\text { Judean Mountains, Israel }\end{array}$ & limestone and dolomite & semi-arid vegetation & 6.8 to 7.9 & -0.21 to -0.13 & 0.08 & 3 & 43.8 to 54.1 & $\begin{array}{l}\text { Emmanuel et al. } \\
\text { (2005) }\end{array}$ & - & - & + \\
\hline Cambisol (C4) & $\begin{array}{l}\text { Stagnic } \\
\text { Cambisol }\end{array}$ & $\begin{array}{l}\text { Rafz, Canton Zurich, N Switzerland, } \\
\left(47^{\circ} 37^{\prime} \mathrm{N}, 8^{\circ} 32^{\prime} E\right)\end{array}$ & $\begin{array}{l}\text { glacial moraine deposit } \pm \text { eolian } \\
\text { silt }\end{array}$ & spruce trees & 3.4 to 4.1 & 0.02 to 0.16 & 0.14 & 6 & 18.0 to 33.0 & $\begin{array}{l}\text { Wiederhold et al. } \\
\text { (2007b) }\end{array}$ & - & - & - \\
\hline Ferralsol (F1) & Laterite & $\begin{array}{l}\text { Nsimi site uphill profile, } \\
122 \mathrm{~km} \text { SE of Yaoundé, Cameroon } \\
\left(3^{\circ} 10^{\prime} \mathrm{N}-11^{\circ} 58^{\prime} \mathrm{E}\right)\end{array}$ & granodiorite & $\begin{array}{l}\text { semi-deciduous } \\
\text { rainforest }\end{array}$ & no data & 0.08 to 0.15 & 0.08 & 7 & 11.3 to 193.7 & $\begin{array}{l}\text { Poitrasson et al. } \\
\text { (2008) }\end{array}$ & + & - & + \\
\hline Ferralsol (F2) & Laterite & $\begin{array}{l}\text { Nsimi site downhill profile, } \\
120 \mathrm{~km} \text { SE of Yaoundé, Cameroon } \\
\left(3^{\circ} 10^{\prime} \mathrm{N}-11^{\circ} 58^{\prime} \mathrm{E}\right)\end{array}$ & granodiorite & $\begin{array}{l}\text { semi-deciduous } \\
\text { rainforest }\end{array}$ & no data & 0.02 to 0.16 & 0.14 & 6 & 30.5 to 148.3 & $\begin{array}{l}\text { Poitrasson et al. } \\
\text { (2008) }\end{array}$ & + & - & + \\
\hline Podzol (P1) & Haplic Podzol & $\begin{array}{l}\text { Flaesheim/ Westphalia, NW Germany } \\
\left(51^{\circ} 430 \mathrm{~N}, 7^{\circ} 120 \mathrm{E}\right)\end{array}$ & $\begin{array}{l}\text { eolian sand deposit } \\
\text { (Pleistocene) }\end{array}$ & pine trees & 3.1 to 4.0 & -0.29 to 0.47 & 0.77 & 10 & 1.9 to 19.4 & $\begin{array}{l}\text { Wiederhold et al. } \\
\text { (2007a) }\end{array}$ & + & + & + \\
\hline Podzol (P2) & Haplic Podzol & $\begin{array}{l}\text { Klosterreichenbach/Black Forest, SW } \\
\text { Germany }\left(48^{\circ} 310 \mathrm{~N}, 8^{\circ} 240 \mathrm{E}\right)\end{array}$ & $\begin{array}{l}\text { hematitic sandstone } \\
\text { (Buntsandstein, Trias) reworked } \\
\text { by periglacial processes }\end{array}$ & spruce and pine trees & 2.7 to 4.6 & -0.02 to 0.51 & 0.53 & 10 & 1.9 to 14.2 & $\begin{array}{l}\text { Wiederhold et al. } \\
\text { (2007a) }\end{array}$ & + & + & + \\
\hline Podzol (P3) & Haplorthod $^{c}$ & $\begin{array}{l}\text { Načetín site, Krušné hory Mountains, } \\
\text { NW Czech Republic }\end{array}$ & $\begin{array}{l}\text { quartzite and biotite - sillimanite } \\
\text { gneiss }\end{array}$ & forest & 3.1 to 4.1 & -0.31 to -0.07 & 0.24 & 6 & 13.2 to 41.5 & $\begin{array}{l}\text { Emmanuel et al. } \\
(2005)\end{array}$ & + & + & + \\
\hline Gleysol (G1) & Haplic Gleysol & $\begin{array}{l}\text { Tettnang, Upper Swabia, S Germany } \\
\left(47^{\circ} 39^{\prime} \mathrm{N}, 9^{\circ} 33^{\prime} \mathrm{E}\right)\end{array}$ & $\begin{array}{l}\text { carbonates - sandy sediments } \\
\text { (Pleistocene) + a layer of loamy } \\
\text { sediments }\end{array}$ & deciduous trees & 5.9 to 7.7 & 0.01 to 0.12 & 0.11 & 6 & 13.0 to 26.7 & $\begin{array}{l}\text { Wiederhold et al. } \\
\text { (2007b) }\end{array}$ & + & + & - \\
\hline Gleysol (G2) & Gleysol & $\begin{array}{l}\text { Kervidy-Naizin, Brittany, NW France } \\
\left(48^{\circ} 00^{\prime} \mathrm{N}, 2^{\circ} 50^{\prime} \mathrm{W}\right)\end{array}$ & $\begin{array}{l}\text { sedimentary Brioverian schist } \\
\text { (older than } 530 \mathrm{Ma} \text { ) }\end{array}$ & poplar trees & 5.4 to 6.3 & -0.15 to 26 & 0.41 & 7 & 10.6 to 63.4 & this study & + & + & - \\
\hline Albeluvisol (Alb) & Albeluvisol & $\begin{array}{l}\text { Kervidy-Naizin, Brittany, NW France } \\
\left(48^{\circ} 00^{\prime} \mathrm{N}, 2^{\circ} 50^{\prime} \mathrm{W}\right)\end{array}$ & $\begin{array}{l}\text { sedimentary Brioverian schist } \\
\text { (older than } 530 \mathrm{Ma} \text { ) }\end{array}$ & poplar trees & 5.4 to 5.6 & 0.00 to 0.26 & 0.26 & 6 & 11.7 to 52.7 & this study & + & + & - \\
\hline Andosol (? $)^{d}$ (And) & $\begin{array}{l}\text { Acrudoxic } \\
\text { Hydrudand }^{c}\end{array}$ & $\begin{array}{l}3500 \mathrm{~mm} \text { rain site, Maui, Hawaii, USA } \\
\left(20^{\circ} 48^{\prime} \mathrm{N}, 156^{\circ} 13-15^{\prime} \mathrm{W}\right)\end{array}$ & basalts & montane rainforest & no data & 0.15 to 0.45 & 0.30 & 4 & 54.3 to 97 & $\begin{array}{l}\text { Thompson et al. } \\
\text { (2007) } \\
\text { Schuur (2001) }\end{array}$ & + & + & $?$ \\
\hline Ultisol (?) (Ult) & \begin{tabular}{|l} 
Plinthic \\
Haplohumults $^{\mathrm{c}}$ \\
\end{tabular} & $\begin{array}{l}\text { Ferncreek series, Mendocino, } \\
\text { California, USA }\end{array}$ & $\begin{array}{l}\text { lithified marine sediments } \\
\text { (Franciscan complex, late } \\
\text { Cretaceous - early Tertiary) }\end{array}$ & $\begin{array}{l}\text { Bishop pine } \pm \text { Douglas } \\
\text { fir } \pm \text { redwood }\end{array}$ & 3.9 to 4.9 & -0.61 to 0.13 & 0.74 & 3 & no data & $\begin{array}{l}\text { Fantle and DePaolo } \\
\text { (2004) }\end{array}$ & + & + & - \\
\hline
\end{tabular}

Table 1: Compilation of bulk Fe isotopic compositions in worldwide soil profiles and characteristics of these soils. 